\title{
THE INVESTIGATION ON PREPARATION OF NANO-SIZED RAW MEDICINAL MATERIAL FROM THE NATURAL SPAR
}

\author{
J. Oyun \\ Chemistry-Technological Department, Faculty of Technology \\ Ulaanbaatar University, Ulaanbaatar,Mongolia, jambaoyuna@yaho..com
}

\begin{abstract}
In the result of many years' investigations we have developed a new version of medical mineral processing technology based on the Mongolian traditional technology. By this technology a nano-sized raw medicinal material has been derived from medical quality natural minerals without involving any kind of chemical reagents and grinder. The size, composition and structure of the resultant product are confirmed by CT microscope, IR spectrometer and X-ray refractometer analysis as being $98 \%$ calcium hydrate $\left(\mathrm{Ca}\left(\mathrm{OH}_{2}\right)\right)$ containing $13.09 \mathrm{~nm}$ lutetium, bounded with milk protein and amino-acid, and is being transformed to the co-ferment (metal-organic) form of $13.51 \mathrm{~nm}$ nano-cluster lactate calcium. This work is the kind of first in the field of nano-technology development in Mongolia and therefore describes some parts of investigations carried out for the derivation of nano-sized new raw medicinal material in more detail.
\end{abstract}

\section{Introduction}

Since the last two decade we carry out investigations on medical quality natural minerals. We have identified and collected about 30 medical quality minerals from the upper, middle and lower Cretaceous coal seams of the South Gobi region of Mongolia and determined their structure, chemical composition [3,5] and origin [4], and are carrying out the first in this field the research on scientific substantiation of the Mongolian traditional technology of processing/taming medical quality minerals.

By this research we revealed the presence of lanthanum group elements, the biological activities of whose have not yet been determined in the world practice, in the medical quality plants and minerals. The analysis have shown that the content of biogenic elements of these lanthanum group elements are in direct proportionality with $\mathrm{Ca}, \mathrm{Fe}, \mathrm{P}, \mathrm{F}$ and $\mathrm{Si}$, and the content of lanthanum elements in the calcium spar is in a constant amount of quantity [5-7]. The detailed analysis of information sources on medical mineral processing of the Mongolian traditional technology (namely, method of selection, preparation, processing phases, quality of products and the synthesis of resultant products with the organic raw materials as final step of drag preparation) and the evidence of analytical investigations we carried out on some steps of raw material processing that related to the 
theory and methodology of modern physics-chemistry and colloid chemistry, suggest us to imply that the Mongolian traditional method of taming medical minerals for drug preparation of that time had been implemented on the nowadays bionanotechnological level $[10,11]$. Mongolians had developed an immense traditional technology of medical mineral taming convenient for their nomadic style of live. To name here some peculiarities of this processing technology: it avoids a mechanical-chemical powdering method in order to preserve the quality of medical minerals, plants, and organic origin tissues contained in it during the activation processes; uses method of neutralization by mixing minerals with each others to purify an organic and non-organic toxic substances from minerals; detoxificates mercury by $\mathrm{Pb}$ and $\mathrm{Sn}$, arsenic - by frying in sand or placing into an ember wrapped by beef $[1,2]$. Overall, traditional methods of processing of medical minerals are based on the principles of detoxification, equalization, activation of their medical qualities and enhancement/nutriting of resultant product by organic substances such as milk, airag (fermented horse milk), vodka, fat or juice depending on drug's expected use. The later step turns the mineral into the metal-organic or co-ferment form. These methods are used as well as in the modern medicine preparation processes.

The uniqueness and advance of medicinal minerals contain in that they do not undergo ecological contamination as in case of plant origin raw medicinal materials and moreover it contains complex of biogenic microelements.

Natural medical minerals will became an important energetic raw material in many branches of human health live such as pharmacy, food supplement and cosmetics in this century.

The objectives of our research were:

- Development of new technological version of processing medical quality natural minerals and derivation of raw material for preparation of mineral medicine based on the Mongolian traditional technology of taming at the level of modern advanced techniques

- Definition of composition, content and size of the derived raw medicinal material by carrying out physical, chemical, mineralogical analysis and evaluation of their quality

\section{Materials and Methods}

We have collected about 30 kinds of mineral samples that were documented as used for drug preparation in the traditional medical practice, from the Gobi region of Mongolia having been guided by the historical name of locations recorded in the ancient classical book [3], oriented and recognized with the assistance of local senior people. The collected samples were classified into 6 groups according to the modern geological naming convention, namely: calcium, iron, silica, gemstones, clayey and salty minerals and were analyzed by modern chemical, physics-chemical and mineralogical equipments in the Research-Experimental-Industry Laboratory of the Chemical Department of the Ulaanbaatar University, Mongolia, and the Nanotechnology Laboratory of the Inner Mongolian Peda- 
gogical University, Huhhot. These analyses include:

- X-ray and chemical silicate analysis for chemical composition determination of natural minerals and technological products

- Complete chemical silicate analysis, AAS-3, ICP-OES, X-ray fluorescence, atom emission spectrum

- Chemical, physical, IR spectral, refractometer, Nikon, AFM and microscopic methods for determination of resultant product's composition, size and chemical bonds.

We carried out the taming process of the natural mineral spar in two steps and after completing of each step the observed changes are determined by the above analysis and evaluated. Correct identification of spar, careful determination of their structure, chemical composition and physical characteristics play a key role in this technology because on this quantitative parameters depends the method of taming and for what kind of drug preparation it will be used. The temperature of decomposition varies depending on the spar structure and composition.

\section{Processing and Results}

We selected "male spar" which corresponds to the Iceland spar according to the modern geological naming convention, to decompose it by thermo-chemical method as burning at the temperature above $850^{\circ} \mathrm{C}$ without losing its primary weight.

The process of spar decomposition can be written as:

$$
\begin{aligned}
& \mathrm{CaCO}_{3} \stackrel{850^{\circ} \mathrm{C}<}{\longrightarrow} \mathrm{CaO} \cdot \mathrm{CO}_{2}+Q \\
& \mathrm{CO}_{3} \rightleftarrows \mathrm{CO}_{2}+\mathrm{O}^{2-}
\end{aligned}
$$

As seen from the Eq. 1 the carbonate calcium spar $\left(\mathrm{CaCO}_{3}\right)$ of hexagonal structure decomposes and forms the calcium oxide $(\mathrm{CaO})$ of cubic structure. Carbon dioxide $\left(\mathrm{CO}_{2}\right)$ does not evaporate but is dissolved into calcium oxide in the form of molecular dispersion which was determined by the main element content $\left(\mathrm{CaO}\right.$ and $\left.\mathrm{CO}_{2}\right)$ in the product after burning. The chemical bond energy is released and free energy increases in two phase medium. The carbon dioxide $\left(\mathrm{CO}_{2}\right)$ created in the result of the taming process has an important role to transfer energy to organism tissues facilitating metabolism and $\mathrm{CaO}$ solubility. $\mathrm{CO}_{2}$ contains ${ }^{14} \mathrm{C}$ isotope while, heavy spar contains ${ }^{18} \mathrm{O}$ isotope [5]. The energy produced during the spar taming was measured by calorimeter and the value of $\mathrm{Q}=-29252.3 \mathrm{~J} / \mathrm{mol}$ energy in the calcium oxide was calculated using the Gibbs formula. The technological flowchart of spar taming process is depicted in Fig. 1 and structural and compositional changes observed during the decomposition of spar by thermo-chemical method are depicted in Fig. 2. 


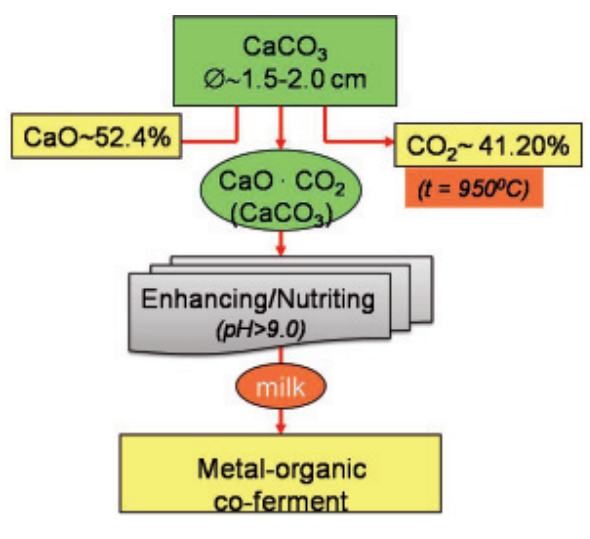

Fig. 1. General sketch of medical spar taming process

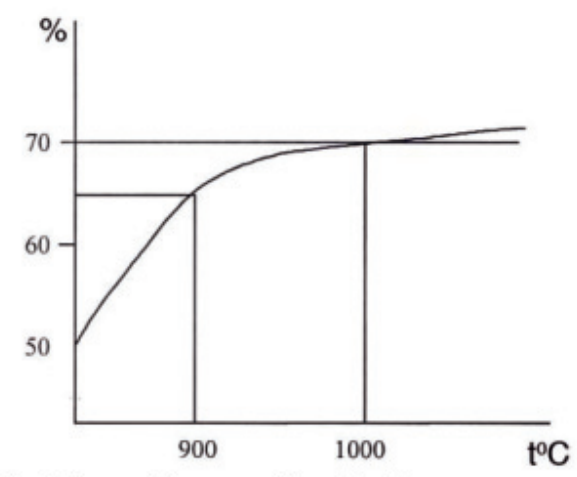

Fig.2. Thermal decomposition of calcium spar and its composition change. Before the burning at $\mathrm{O}^{\circ} \mathrm{C}-\mathrm{CaO} \square 52.4 \%, \mathrm{CO}_{2} \square 44.8 \%$, during the burning at $920^{\circ} \mathrm{C}-\mathrm{CaO} \square 67 \%, \mathrm{CO}_{2}$ $\square 29.2 \%$, at $1000^{\circ} \mathrm{C}-\mathrm{CaO} \square 70 \%, \mathrm{CO}_{2} \square 29.6 \%$

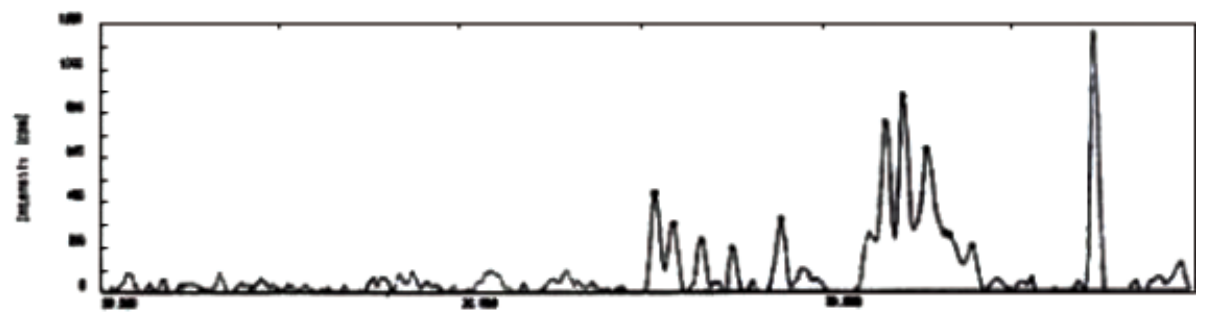

Fig. 3. X-ray pattern of the natural spar

The structural changes occurred in the thermo-chemical taming process can be seen from the comparative X-ray analysis of tamed spar (Fig.3) and natural spar (Fig. 4). 

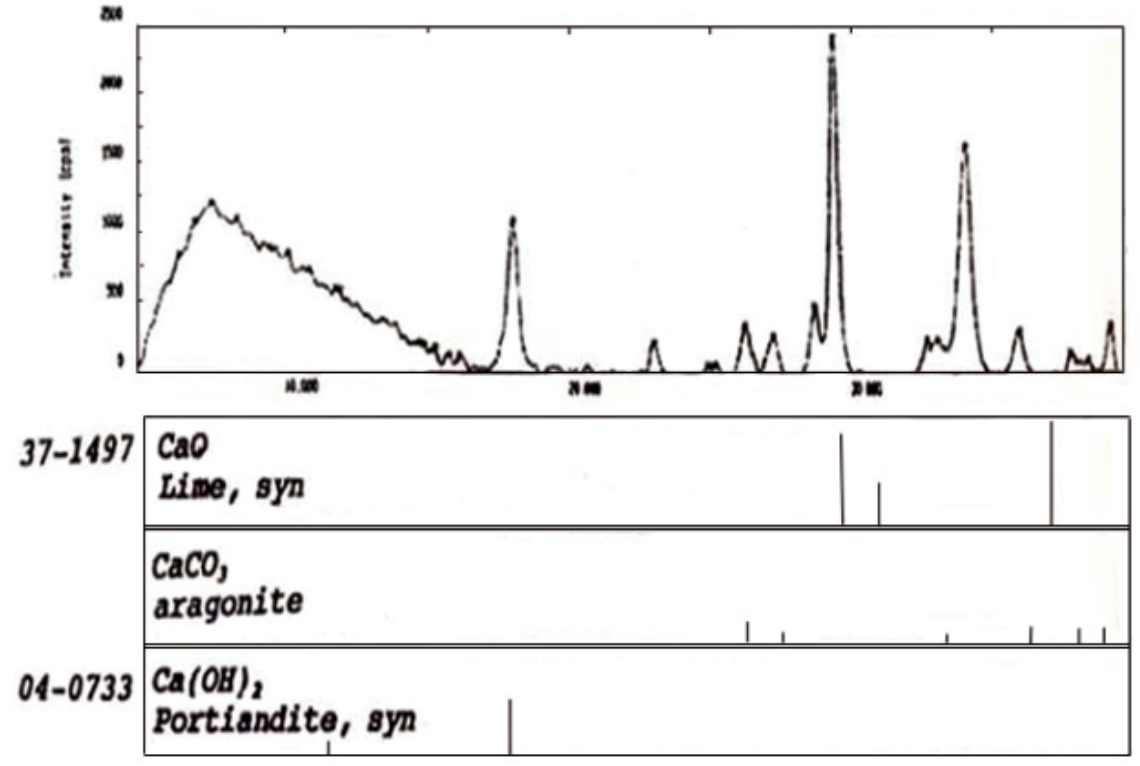

Fig. 4. X-ray pattern of the tamed spar

The spar raw medicinal material we derived by this taming method had been included to the drugs for improving heart, brain, nerve, lunge and stomach activities, and to the drugs for preventing osteoporosis.

3.1 The change after nutriting of tamed spar

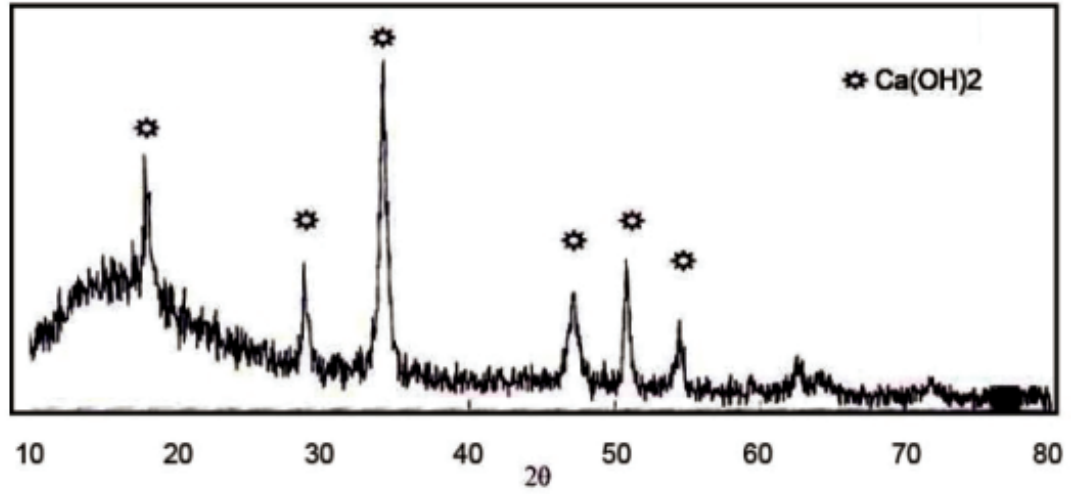

Fig. 5. Calcium hydroxide content in the nutrited spar (98\% purity) 
The compositional analysis of the spar, enhanced/nutrited by cow milk, is performed by the X-ray fluorescence and its purity shown in Fig. 5 and the characteristics of the created metal-organic bond is shown in Fig.6, respectively. The infrared (IR) spectral analysis of its bond structure (Fig.7) shows that after nutriting by milk acids the active ligands $\left(\mathrm{COO}^{-}, \mathrm{C}-\mathrm{H}, \mathrm{C}-\mathrm{C}, \mathrm{O}-\mathrm{H}, \mathrm{COOH}\right)$ are formed that are able to create a metal-organic composition.

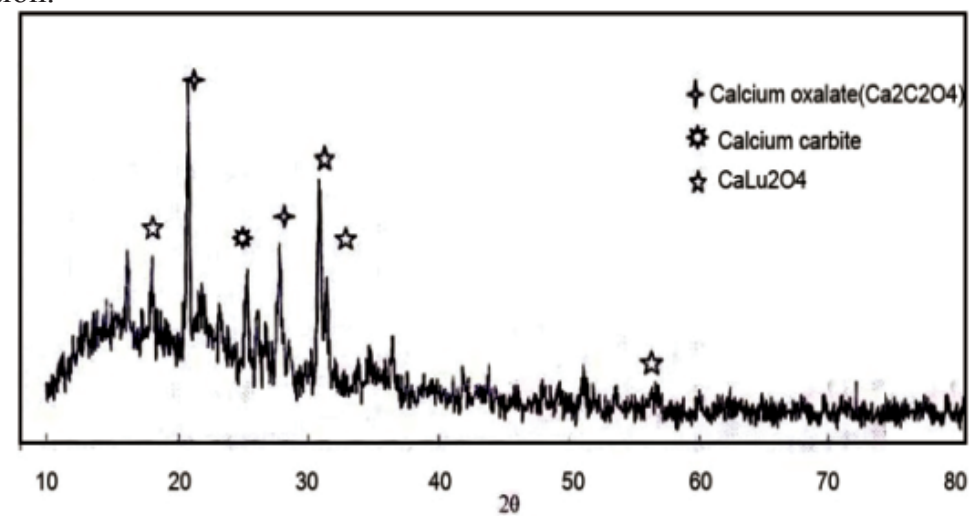

Fig. 6.Characteristics of metal-organic bond in the structure of the tamed spar

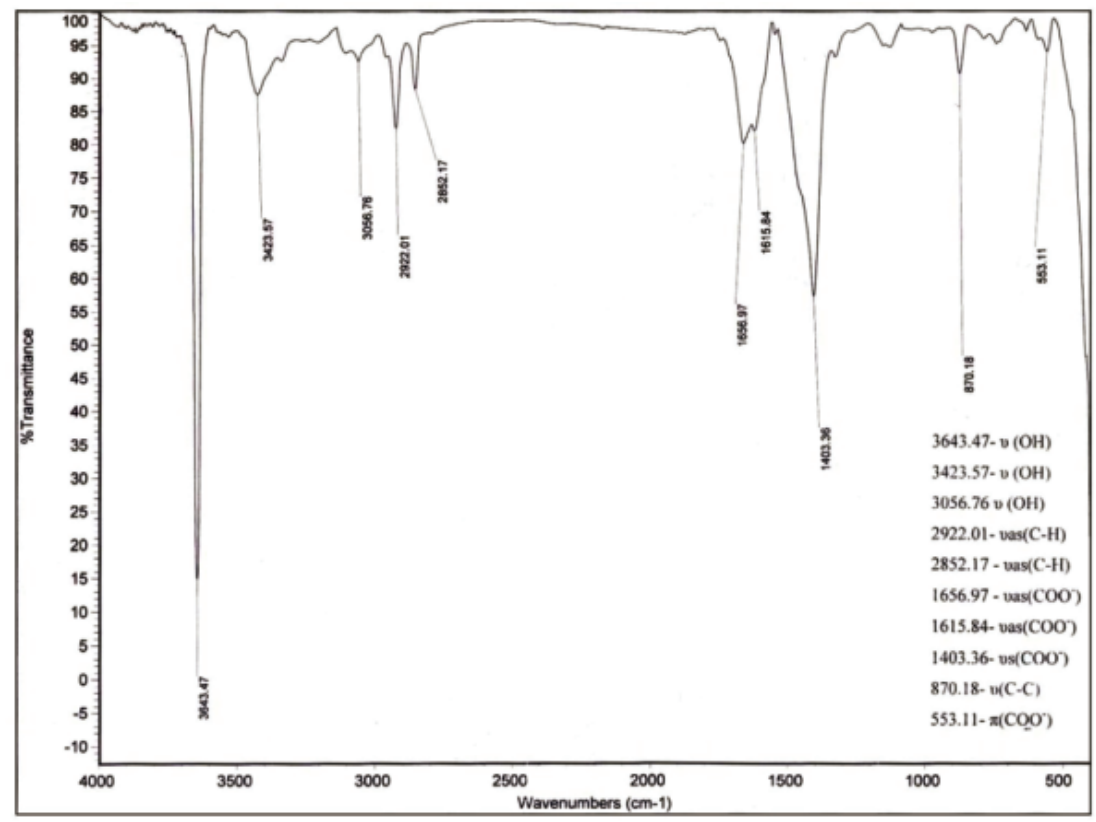

Fig. 7. IR spectrum of enhanced/nutrited spar 
The electron microscope (ST) analysis determined the purity of the tamed and nutrited by milk spar as to be of $98 \% \mathrm{Ca}(\mathrm{OH})_{2}$ with the size of $10^{-11}-10^{-9} \mathrm{~m}$. It is seen that its $\mathrm{Ca}$ creates with lanthanum group elements such compounds as calcium-lutetium oxalate $\left(\mathrm{CaLuC} \mathrm{O}_{4}\right)$ of lactic acid, calcium oxalate $\left(\mathrm{CaC}_{2} \mathrm{O}_{4}\right)$, calcium carbide $\left(\mathrm{CaC}_{2}\right)$ (Fig. 6). As we mentioned above, our previous study defined that lanthanides are contained in a natural spar in a constant amount of order $\left(10^{-2}-10^{-3} \%\right)$ [10]. Diffractometer and IR spectrometer analysis show the emergence of lutetium and its presence as an accompaniment of spar calcium (Fig. 6).

From lanthanides the Lu has luminescence and magnetic qualities therefore it is more sensible to the above mentioned instruments. Firstly Yanch (1926), later Varaskina, and Peshkova determined that the lanthanides create lactate with lactic acids, bridged by oxygen.

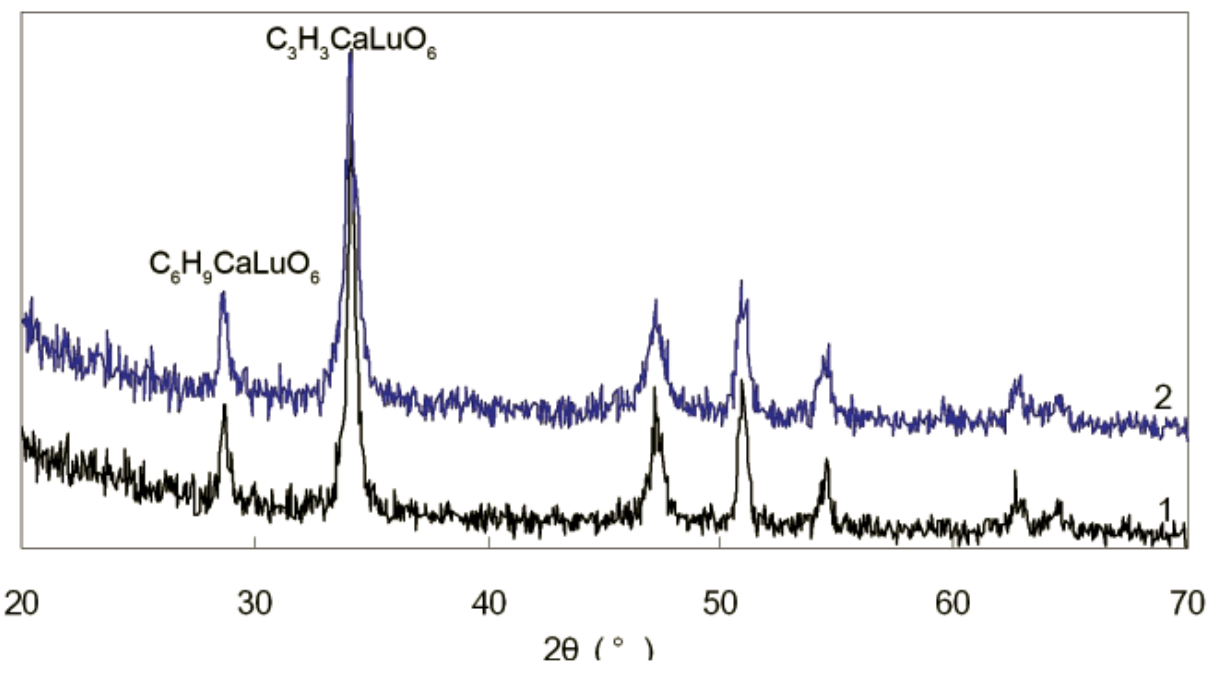

Fig. 8. Sample analysis by $\mathrm{X}$-ray diffractometer

X-ray diffraction patterns of the spar show $\mathrm{C}_{6} \mathrm{H}_{9} \mathrm{LuO}_{6}$ peak at refraction index of $2 \theta=20.719, \mathrm{C}_{3} \mathrm{H}_{3} \mathrm{LuO}_{6}$ peak in $\mathrm{P} 350969$ card at the refraction index of $2 \theta=34.011$ (Fig. 8 ) suggesting that Lu connected with the lactate calcium in the lactic acid environment. Hydrate peaks are revealed at $2 \theta=47.212,50.960,54.462,62.623,64.450$ respectively.

Based on the X-ray diffractometer's analysis we calculated the size of $\mathrm{Lu}$ using the Bragg's formula (Eq. 2) as to be 13.09-13.51 nm.

$$
C=\lambda \cdot R \cdot \frac{(0.89-0.09)}{\beta \cdot \cos \alpha}
$$

The above value is consistent with the analysis results of transmission electron microscopes performed at the Nanotechnological laboratories of Hohhot and Taiwan, which 
defined the structural composition of this newly created metal-organic compound and the grain size to be as $13.09-13.51 \mathrm{~nm}$. This analysis also confirms that lanthanides create with lactic acid the complex compound (co-ferment) of the $\mathrm{CaLn}\left(\mathrm{CH}_{3} \mathrm{CHOHCOO}\right)_{3}$ form, and $\mathrm{Ca}$ and $\mathrm{Lu}$ bond with lactic acid by oxygen.

Table 1a. Main compounds (\%) of newly derived raw medical material defined by $\mathrm{x}$-ray fluorescence method

\begin{tabular}{|c|c|c|c|c|c|c|c|c|c|c|}
\hline $\mathrm{SiO}_{2}$ & $\mathrm{TiO}_{2}$ & $\mathrm{Al}_{2} \mathrm{O}_{3}$ & $\mathrm{Fe}_{2} \mathrm{O}_{3}$ & $\mathrm{MnO}$ & $\mathrm{MgO}$ & $\mathrm{CaO}$ & $\mathrm{Na}_{2} \mathrm{O}$ & $\mathrm{K}_{2} \mathrm{O}$ & $\mathrm{P}_{2} \mathrm{O}_{5}$ & $\begin{array}{c}\mathrm{CO}_{2}, \mathrm{C}_{\text {opr }} \\
\mathrm{H}_{2} \mathrm{O} \text {, etc }\end{array}$ \\
\hline 0.12 & $<0.001$ & $<0.003$ & 0.04 & 0.002 & 0.29 & 67.57 & $<0.005$ & 0.022 & 0.12 & 30.41 \\
\hline
\end{tabular}

Table 1b. Microelements content, $\mathrm{mg} / \mathrm{kg}$

\begin{tabular}{|c|c|c|c|c|c|c|c|c|}
\hline $\mathrm{F}$ & $\sum$ & $\mathrm{As}$ & $\mathrm{Ba}$ & $\mathrm{Ce}$ & $\mathrm{Co}$ & $\mathrm{Cs}$ & $\mathrm{Cu}$ & $\mathrm{Ga}$ \\
\hline$<0.05$ & 98.50 & $<$ & $<5$ & $<20$ & $<5$ & $<25$ & 11 & $<3$ \\
\hline $\mathrm{Hf}$ & $\mathrm{La}$ & $\mathrm{Mo}$ & $\mathrm{Nb}$ & $\mathrm{Nd}$ & $\mathrm{Pr}$ & $\mathrm{Pb}$ & $\mathrm{Ni}$ & $\mathrm{Lu}$ \\
\hline$<15$ & $<30$ & $<5$ & $<3$ & $<50$ & $<30$ & $<5$ & $<5$ & $<30$ \\
\hline
\end{tabular}

The method of taming directly influences to the drug quality and the color variation depends on the amount of presence of $\mathrm{Fe}, \mathrm{Cu}, \mathrm{Co}, \mathrm{Mn}$ elements in its composition. Accordingly, taste and smell are also changed. The quality of drug follows its taste and smell, and an incorrect taming may decrease the quality of drug and even turn it into the toxic substances. Therefore, after completion of taming process an accurate evaluation analysis have to be done.

The supplementary raw materials are selected based on the expected use of the drug. The supplementary raw materials affect to the physical properties of mineral, destroy the structure, increase the solubility, neutralize and smooth too acidic or too alkaline qualities and regulate hot, cool and mild properties while enhancing/nutriting the drug. For supplementary raw material we chose cow milk, the protein of which is amorphous substances existing in the form of $\mathrm{Ca}, \mathrm{P}$ compound. Molecules of protein contain both amino and carboxide groups. Lactic acid separates calcium from the calcium casein in the oxidation-reduction process and creates soluble casein (protein) or calcium lactate. Except the casein, albumin, and globulin, milk contains also other kind of proteins and nonprotein nitrogen substances. The transformer of calcium to the bone is protein. Many amino-acids such as valine, leicine, lysine, threonin and isoleicine have an important role for calcium exchange process. An addition of lactose to the food improves the absorption of ${ }^{45} \mathrm{Ca}$ isotope. The main physiological function of $\mathrm{Ca}$ is to affect the cell membrane and increase its main compound - biocolloide.

The element content in the traditional drugs shijid-6 and gurgem-9 was determined by Inductively Coupled Plasma (ICP) spectrometer (Table 2 and Table 3). The result of analysis shows that the quantity of element components in the traditional drugs do not exceeds those of in the human organism, and the composition of each raw materials varies 
like decrease and neutralize or increase of some mixture elements providing the complete element equalization, which confirms that the created product is modern bionanotechnological nano-sized product.

Table 2. Gurgem-9

\begin{tabular}{|c|c|c|c|c|c|}
\hline No. & Element & Content, $\%$ & No. & Element & Content, \% \\
\hline 1 & $\left(\mathrm{H}_{2} \mathrm{O}+\mathrm{C}_{\text {org }}\right)$ & 0.72 & 15 & $\mathrm{Zn}$ & 0.007 \\
\hline 2 & $\mathrm{Fe}$ & 0.05 & 16 & $\mathrm{Ag}$ & 0.0002 \\
\hline 3 & $\mathrm{Ca}$ & 0.05 & 17 & $\mathrm{Sb}$ & 0.002 \\
\hline 4 & $\mathrm{Mg}$ & 0.02 & 18 & $\mathrm{Sn}$ & 0.0001 \\
\hline 5 & $\mathrm{Na}$ & 0.003 & 19 & $\mathrm{Ga}$ & 0.0007 \\
\hline 6 & $\mathrm{Ti}$ & 0.15 & 20 & $\mathrm{Sr}$ & 0.01 \\
\hline 7 & $\mathrm{Mn}$ & 0.002 & 22 & $\mathrm{Ba}$ & 0.20 \\
\hline 8 & $\mathrm{Cr}$ & 0.001 & 23 & $\mathrm{Zr}$ & 0.0007 \\
\hline 9 & $\mathrm{Ni}$ & 0.00007 & 24 & $\mathrm{Be}$ & 0.0001 \\
\hline 10 & $\mathrm{Co}$ & 0.0015 & 25 & $\mathrm{Sc}$ & 0.0005 \\
\hline 11 & $\mathrm{~V}$ & 0.0001 & 26 & $\mathrm{La}$ & 0.0007 \\
\hline 12 & $\mathrm{Mo}$ & 0.002 & 27 & $\mathrm{Ce}$ & 0.002 \\
\hline 13 & $\mathrm{Cu}$ & 0.0015 & 28 & $\mathrm{Y}$ & 0.01 \\
\hline 14 & $\mathrm{~Pb}$ & & & 0.015 \\
\hline
\end{tabular}

Table 3. Shijid-6

\begin{tabular}{|c|c|c|c|c|c|}
\hline \multicolumn{7}{|c|}{ Spectral analysis result } \\
\hline No. & Element & Content, \% & No. & Element & Content, \% \\
\hline 1 & $\left(\mathrm{H}_{2} \mathrm{O}+\mathrm{C}_{\text {org }}\right)$ & 0.21 & 15 & $\mathrm{Mo}$ & 0.0002 \\
\hline 2 & $\mathrm{Fe}$ & 0.02 & 16 & $\mathrm{Cu}$ & 0.003 \\
\hline 3 & $\mathrm{Ca}$ & 0.07 & 17 & $\mathrm{~Pb}$ & 0.0015 \\
\hline 4 & $\mathrm{Mg}$ & 0.02 & 18 & $\mathrm{Zn}$ & 0.0001 \\
\hline 5 & $\mathrm{Na}$ & 0.001 & 19 & $\mathrm{Ag}$ & 0.0001 \\
\hline 6 & $\mathrm{Fe}$ & 0.30 & 20 & $\mathrm{Sb}$ & 0.0005 \\
\hline 7 & $\mathrm{Mn}$ & 0.05 & 21 & $\mathrm{Sn}$ & 0.01 \\
\hline 8 & $\mathrm{Na}$ & 0.003 & 22 & $\mathrm{Ga}$ & 0.07 \\
\hline 9 & $\mathrm{Ti}$ & 0.0007 & 23 & $\mathrm{Sr}$ & 0.001 \\
\hline 10 & $\mathrm{Mn}$ & 0.0005 & 24 & $\mathrm{Ba}$ & 0.0007 \\
\hline 11 & $\mathrm{Cr}$ & 0.002 & 25 & $\mathrm{Zr}$ & 0.0005 \\
\hline 12 & $\mathrm{Ni}$ & 0.00015 & 26 & $\mathrm{~Pb}$ & 0.003 \\
\hline 13 & $\mathrm{Co}$ & 0.002 & 27 & $\mathrm{Be}$ & 0.01 \\
\hline 14 & $\mathrm{~V}$ & 0.003 & 28 & $\mathrm{Sc}$ & 0.015 \\
\hline
\end{tabular}




\section{Conclusion}

We developed a new technological version of processing medical quality natural minerals and derived the raw medicinal material for preparation of mineral medicine based on the Mongolian traditional technology of taming at the level of modern advanced techniques. The resultant products were analyzed by physical, chemical, mineralogical methods, the composition, content and size were defined and their qualities evaluated. The nano-size of the newly created raw medicinal material from the natural spar was determined by the ST and AF microscopes. Based on our investigations we conclude:

1. The developed new version of taming process based on the Mongolian traditional technology turns the medical mineral into the nano-size (13.09-13.51 $\mathrm{nm}$ ) and into co-ferment form of nano-cluster structure confirming the process is being bionanotechnological method.

2. The metal-organic (co-ferment) compound created by enhancing/ nutriting the tamed product by milk has size of $13.09 \mathrm{~nm}$, contains Lu, and its $98 \%$ $\mathrm{Ca}(\mathrm{OH})_{2}$ creates the chemical bound with lactic acid's active ligands (COO, C-C, $\mathrm{C}-\mathrm{H}, \mathrm{COOH}, \mathrm{OH}$ etc. $)$ forming acid $\left(\mathrm{CaLuC}_{2} \mathrm{O}_{4}\right)$ and $\mathrm{CaLu}\left(\mathrm{CH}_{3} \mathrm{CHOHCOO}\right)_{3}$ or $\mathrm{Ca}\left(\mathrm{CH}_{3} \mathrm{CHOHCOO}\right)_{2}, \mathrm{Lu}\left(\mathrm{CH}_{3} \mathrm{CHOHCOO}\right)_{2}$.

\section{Reference:}

[1] Danzanvaanchig. Gegeen khumrug, XVIII century (in Mongolian).

[2] Chud-shi. Memorial of middle century Tibetan medicine. Translation from Tibetan. Novosibirsk, Nauka. 1988, pp 100 (in Russian).

[3] Luvsanchultem. Science of recognition of medical gemstones, soil and rocks. XYIIXYIII century Tibetan manuscript.

[4] Ishbaljir. Crystal mirror for recognition of name and medical minerals. Mineral drops. XYII century, pp. 1704-1810 (in Mongolian)

[5] Ishdanzanvaanjil (1874-1907). Jurdushil. XIX century, Inner Mongolia, Ordos.

[6] Ishbaljir (1704-1788). Anagaakh shinjlehuin rashaany dusal, XVIII century. (in Mongolian).

[7] Oyun, J. Physical and chemical technological studies of medical minerals of Mongolia. Ulaanbaatar. 2006, pp. 430, (in Mongolian).

[8] Oyun, J. Studies of origin of medical minerals of Mongolia. The $9^{\text {th }}$ Asian Conference on Analytical Sciences, Jeju, Korea, 7-9 November, 2007.

[9] Oyun, J. Study of natural medicinal quality minerals and plants, their use as nutrition complement. The first international symposium on chemistry of Herbal medicine and Mongolian drug, Hoh hot, July 2007.

[10] Oyun, J., Analytic study of low content lanthanoids concentration in minerals by polymeric reagents. $25^{\text {th }}$ Rare Earth Research Conference, Tuscaloosa, AL, USA, 22-28 June, 2008.

[11] Oyun, J., Ch. Tserenkhuu and Sh. Munkhjargal. Chemical-biological studies of rare earth's elements in the medical minerals of Mongolia. $10^{\text {th }}$ Asian Conference on Analytical Sciences, Kuala Lumpur Malaysia, 13 August 2009. 
[12] Oyun, J. Chemical-technological study of preparing nano-sized medical raw material from the medical quality natural mineral. J. Mongolian Geoscientist. No. 34, pp.194, Ulaanbaatar, 2009 (in Mongolian).

[13] Oyun, J. The Mongolian traditional nanotechnology of medical mineral taming and results of research on preparing nano-sized mineral medicine. J. Mongolian Medical Science, No.3, pp.31, Ulaanbaatar, 2009 (in Mongolian).

[14] Oyun, J. Nano-sized medical raw material developed firstly in Mongolia. In J. : The new treating info, pp.7, Ulaanbaatar, September, 2009 (in Mongolian). 